\title{
SURVEY Of OBESITY AMONG KINDERGARTEN GIRLS AND THEIR MOTHER'S AWARENESS
}

\author{
By \\ Sahloul ; O.T
}

Fac. of Specific Education,

Damietta. Univ.

Research gournal Specific Fducation

Faculty of Specific Fducation

gMansoura University

ISSUE NO. 41, JANUARY. 2016

مجلة بحوث التربية النوعية - جامعة المنصورة

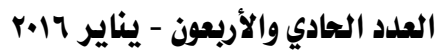




\section{SURVey Of Obesity AMONg KINDergarten GirLS and THEIR MOTHER'S AWARENESS}

Sahloul ; O.T

\section{Abstract}

This study was undertaken to construct percentile curves of body mass index (BMI) and cut off points for overweight and obesity of kindergarten children girls in Damietta, as well as study of the social status and measuring height, weight, BMI and (Mid-Upper-Arm Circumference) MUAC, then make questionnaires for the nutritional awareness of mothers, and questionnaires to track the child's dietary intake, for thirty nine children girls, aged 4-6 years from Damietta, measured during 2014. The (BMI) percentile curves for Damietta children. Obtained results indicated that: $5.13 \%$ of girls were Underweight, $69.32 \%$ were in Normal weight, $7.65 \%$ were in Overweight, and $17.59 \%$ were in Obesity, The study also proved that no relationship between BMI in children and mothers food awareness, this need to reconsidering of the food recommendations for children in all age stages.

Key Words: Prevalence of obesity- child girls obesity - BMI

\section{Introduction}

The prevalence of childhood obesity increasing rapidly worldwide, it has been estimated that over 22 million children under the age of 5 are severely overweight, and one in 10 children are overweight. This global average reflects a wide range of prevalence levels, with the prevalence of overweight in Africa and Asia averaging well below $10 \%$ and in the Americas and Europe above 20\%. (Kosti and Panagiotakos ;2006)

WHO (2015) defined Overweight and obesity as abnormal or excessive fat accumulation that may impair health.

\footnotetext{
* Fac. of Specific Education, Damietta. Univ.
} 
There has been a dramatic rise in the numbers of children under 5 years of age who are overweight. According to the new 2013 United Nations Children's Fund (UNICEF), World Health Organization (WHO) and World Bank estimates, between 2000 and 2013, the number of overweight children worldwide increased from 32 million to 42 million. The prevalence of childhood overweight is increasing in all regions of the world, particularly in Africa and Asia (WHO, 2014).

42 million children under the age of 5 were overweight or obese in 2013(WHO, 2015).

Childhood obesity has reached epidemic levels in developed countries. Twenty five percent of children in the US are overweight and $11 \%$ are obese. About $70 \%$ of obese adolescents grow up to become obese adults (Whitaker et al., 1997; Nicklas et al., 2001).

The prevalence of childhood obesity is in increasing since 1971 in developed countries. In some European countries such as the Scandinavian countries the prevalence of childhood obesity is lower as compared with Mediterranean countries, nonetheless, the proportion of obese children is rising in both cases (Livingstone, 2001).

The highest prevalence rates of childhood obesity have been observed in developed countries, however, its prevalence is increasing in developing countries as well. The prevalence of childhood obesity is high in the Middle East, Central and Eastern Europe (James, 2004).

In Saudi Arabia, one in every six children aged 6 to 18 years old is obese (Kelishadi et al., 2003).

prevalence among preschool children between age group of 2-5year-old girls and boys has increased from 5.0 to $10 \%$ between 1976-1980 and 2007-2008 and it has increased from 6.5 to $19.6 \%$ among age group of 6-11 year olds. The data collected for the same period shows that the adolescent (age group 12-19 years) obesity has increased from 5.0 to $18.1 \%$ ( Ogden et al.,2010) 
(Almeida et al.,2003) suggested that (Mid-Upper-Arm Circumference) MUAC was an adequate alternative method for obesity screening in preschool children.

This was proved by (Mazıcıo glu et al.,2010) in children aged 6-17 years. Age-related MUAC cutoffs have been reported for children in two countries, Brazil and Turkey.

Making parents aware that obesity is a health problem might be the first step in promoting a healthy lifestyle and a healthy body weight among school-aged children. Although there is no direct evidence that increasing parents' awareness of children's weight problems would prevent overweight and obesity in children, there is evidence that parents' awareness and monitoring can prevent risky behaviour among children and adolescents (Stanton, 2004).

Schanzenbach (2009) find that children who consume school lunches are more likely to be obese than those who brown bag their lunches even though they enter kindergarten with the same obesity rates.

The increase in fast food consumption parallels the escalating obesity epidemic, raising the possibility that these 2 trends are causally related. Characteristics of fast food previously linked to excess energy intake or adiposity include enormous portion size, high energy density, palatability, excessive amounts of refined starch and added sugars, high fat content, and low levels of dietary fiber (Schlosser , 2002, Cummins et al.,2005, MacIntyre et al.,2005, Simmons et al.,2005, Keynote: 2006, Fraser et al., 2010 and NHS, 2011).

\section{Subjects and Methods}

The random sample was 39 children from $4: 6$ years aged. They selected from Damietta Government to applicat some Anthropometric measurements.

The study Contains three Questionnaires; Questionnaire(1): General data: name, age, number of absences, Family member, child arrangement and asking child mother for recognize child habit. Questionnaire(2): anthropometric measures: height (cm), weight(k.g), body 
= Survey of Obesity Among Kindergarten Girls and Their mother's Awareness

mass index (BMI), and mid-upper-arm circumference $(\mathrm{cm})$. Questionnaire(3): for girls mothers to recognize food awareness.

Height and weight were measured to the nearest $0.1 \mathrm{~cm}$ and $0.1 \mathrm{~kg}$, respectively.

BMI as an indicator of obesity was calculated according to the following formula:

$$
\text { BMI }=\frac{\text { Weight }(\mathrm{Kg})}{\text { Height }\left(\mathrm{m}^{2}\right)}
$$

The grades of obesity utilizing the BMI are described at (Table 1)

Table 1: The grade of obesity utilizing the BMI.

\begin{tabular}{|c||c||}
\hline Weight Status Category & Percentile Range \\
\hline \hline Underweight & Less than the 5th percentile \\
\hline Healthy weight & 5th percentile to less than the 85th percentile \\
\hline Overweight & 85th to less than the 95th percentile \\
\hline Obese & Equal to or greater than the 95th percentile \\
\hline
\end{tabular}

The National Center for Health Statistics in collaboration and the National Center for Chronic Disease Prevention and Health Promotion (2000).

mid-upper-arm circumference (MUAC) was measured using a flexible tape at the midway between the olecranon and acromial process on the upper right arm.

All measurements were taken twice, and the two measurements were averaged for analysis. (Qiang et al., 2014)

\section{RESULT AND DISCUSSION}

\section{Anthropometric data:}

Table 2 and fig. 1 showed that frequency and distribution of Body mass index.

It is noted that 2 of the girls $(5.13 \%)$ were underweight, $27(69.32 \%)$ were in normal weight, $3(7.65 \%)$ were in overweight, and $7(17.59 \%)$ were in obesity, total of overweight and obesity were 10 cases $(25.6 \%)$. 
These result in the same trend of study in Saudi Arabia, reported that one in every six children aged 6 to 18 years old is obese (AlNuaim et al., 1996).

On the other hand Since 1981, BMI has increased at the rate of nearly $0.1 \mathrm{~kg} / \mathrm{m}^{2}$ per year for both sexes at most ages, indicating a clear secular trend toward an increase in BMI of Canadian children (Mark and Douglas, 2000).

In this respect (Nicklas et al., 2001) reported that the prevalence of overweight among girls from $15 \%$ to $23.6 \%$. Twenty five percent of children in the US are overweight and $11 \%$ are obese.

This finding are in agreement with (Hassan, 2003) who found that the girls from 2-6 year $8.2 \%$ of the girls were underweight, $85.4 \%$ were in normal weight, $3.8 \%$ were in overweight, and $2.6 \%$ were in obesity.

Table (2): Frequency distribution of Body mass index (BMI).

\begin{tabular}{|c||c|c|c|c|c|c|c|c|}
\hline \hline \multirow{3}{*}{ BMI } & \multicolumn{2}{|c|}{ Under weight } & \multicolumn{2}{|c|}{ Normal weight } & \multicolumn{2}{c|}{ Over weight } & \multicolumn{2}{|c|}{ Obesity } \\
\cline { 2 - 9 } & $\mathrm{N}$ & $\%$ & $\mathrm{~N}$ & $\%$ & $\mathrm{~N}$ & $\%$ & $\mathrm{~N}$ & $\%$ \\
\cline { 2 - 9 } & 2 & $\mathbf{5 . 1 3 \%}$ & $\mathbf{2 7}$ & $\mathbf{6 9 . 2 3 \%}$ & $\mathbf{3}$ & $\mathbf{7 . 6 9 \%}$ & $\mathbf{7}$ & $\mathbf{1 7 . 9 5 \%}$ \\
\hline
\end{tabular}

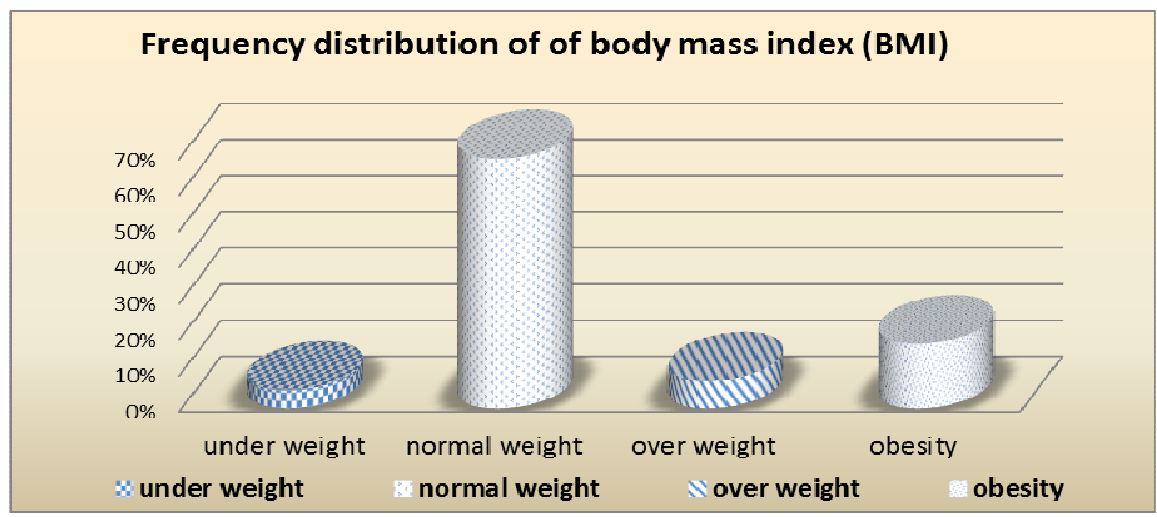

Fig.(1): Frequency distribution of Body mass index (BMI).

$\mathrm{N}$ : number of girls 
= Survey of Obesity Among Kindergarten Girls and Their mother's Awareness

Table (3) Distribution of mid-upper-arm circumference (MUAC).

All the girls were overweight and obesity

This finding were similar to those reported by (Qiang et al., 2014) the MUAC cutoff values for elevated BMI were calculated to be approximately $18.9-23.4 \mathrm{~cm}$ in boys and girls.

Table (3) Distribution of mid-upper-arm circumference(MUAC).

\begin{tabular}{||c||c|c|c|c|c|c||}
\hline \multirow{3}{*}{ MUAC } & \multicolumn{2}{|c|}{ Under weight } & \multicolumn{2}{c|}{ Normal weight } & \multicolumn{2}{c|}{ Over weight and Obesity } \\
\cline { 2 - 7 } & $\mathbf{N}$ & $\%$ & $\mathbf{N}$ & $\%$ & $\mathbf{N}$ & $\%$ \\
\cline { 2 - 7 } & $\mathbf{0}$ & $\mathbf{0 \%}$ & $\mathbf{0}$ & $\mathbf{0 \%}$ & $\mathbf{3 9}$ & $\mathbf{1 0 0 \%}$ \\
\hline
\end{tabular}

$\mathrm{N}$ : number of girls

\section{Food awareness:}

Table 4 and fig.2 BMI distribution in girls as affected with food awareness.

The result showed that, in high food awareness no cases were under weight, $6(21.4 \%)$ were normal weight, 1(3.6\%) were overweight, and $1(3.6 \%)$ were obesity, while in medium food awareness $1(3.6 \%)$ were under weight, 7 (25\%) were normal weight, no cases were overweight, and 2(7\%) were obesity, and in bad food awareness no cases were under weight, 9 (32.1\%) were normal weight, $1(3.6 \%)$ were overweight, and no cases were obesity.

Medium food awareness resulted in higher percentage of obesity, while little food awareness resulted in higher percentage of normal weight.

There result were in agreement with Lowes and Tiggemann (2010) they showed that for dieting awareness there was no significant gender effect, although level of dieting awareness increased with age. a substantial proportion of young children have internalized societal beliefs concerning the ideal body shape and are well aware of dieting as a means for achieving this ideal. In particular, the desire for thinness emerges in girls at around age 6 


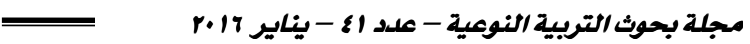

Table (4): BMI distribution in girls as affected with food awareness

\begin{tabular}{|c|c|c|c|c|c|c|c|c|}
\hline \multirow{2}{*}{ food awareness } & \multicolumn{2}{|c|}{ Under weight } & \multicolumn{2}{|c|}{ Normal weight } & \multicolumn{2}{|c|}{ Over weight } & \multicolumn{2}{|c|}{ Obesity } \\
\hline & $\mathbf{N}$ & $\%$ & $\mathbf{N}$ & $\%$ & $\mathbf{N}$ & $\%$ & $\mathbf{N}$ & $\%$ \\
\hline high food awareness & $\mathbf{0}$ & $0 \%$ & 6 & $21.4 \%$ & 1 & $3.6 \%$ & $\mathbf{1}$ & $3.6 \%$ \\
\hline Medium food awareness & 1 & $3.6 \%$ & 7 & $25 \%$ & $\mathbf{0}$ & $\mathbf{0 \%}$ & 2 & $7 \%$ \\
\hline Little food awareness & $\mathbf{0}$ & $0 \%$ & 9 & $32.1 \%$ & 1 & $3.6 \%$ & $\mathbf{0}$ & $\mathbf{0 \%}$ \\
\hline
\end{tabular}

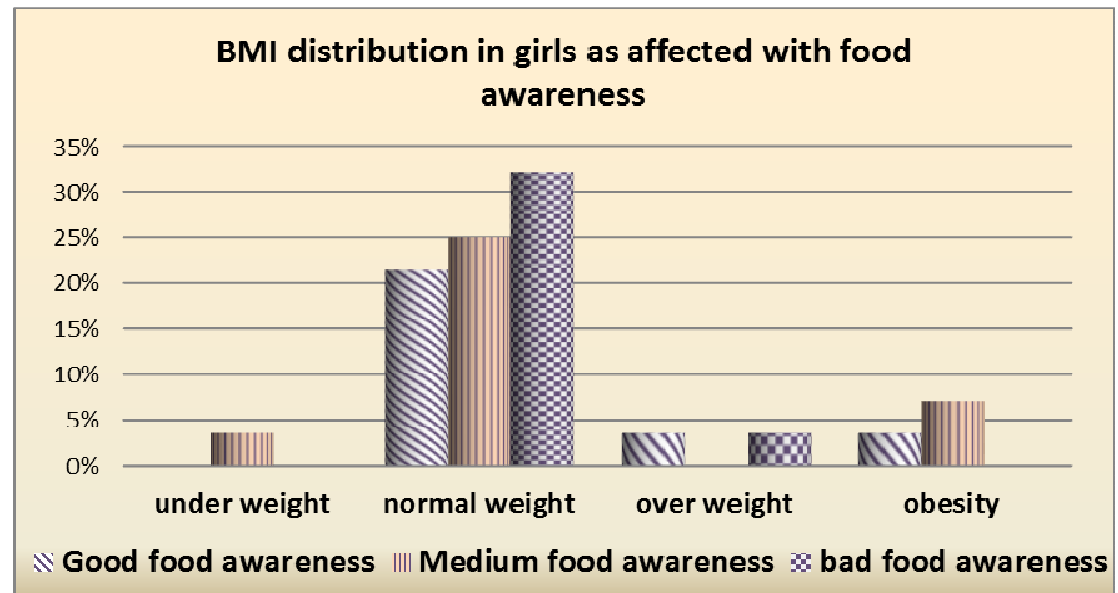

fig. (2) BMI distribution in girls as affected with food awareness.

$\mathrm{N}$ : number of girls

\section{General data:}

Table 5 and fig. 3 BMI distribution as affected with times of absent girls per week.

The result showed that, two cases were underweight one don't absences, the other absences 1day weekly, while obesity the most of girls also don't absences or absences 1day weekly, then normal weight most girls weren't absences, and overweight the most of girls weren't absences.

In the case of girls not absent 3 from 24(12.5\%) were obesity, but in the case of one time absence 3 from 12(25\%) were obesity, in the same 
trend was in two time absence 1 from 3(33.3\%) were obesity, these result reveled that attendant girls were lesser in obesity than absence girls.

This finding are in agreement with (Li et al., 2012) found that the means of school days missed in the last 12 months were not statistically different between the normal-weight, overweight and obese groups, $3.79 \pm 0.56,3.86 \pm 0.38$ and $4.31 \pm 0.01$ days, respectively. However, when $>2$ days missed per school month was defined as severe absence, the prevalence of severe absence were $1.57 \%, 2.99 \%$ and $4.94 \%$ respectively, among 6-11year-old children with normal, overweight and obese.

Table (5): BMI distribution as affected with times of absent girls per week

\begin{tabular}{|c|c|c|c|c|c|c|c|c|c|c|}
\hline \multirow{2}{*}{ Number of absences } & \multicolumn{2}{|c|}{ Under weight } & \multicolumn{2}{|c|}{ Normal weight } & \multicolumn{2}{|c|}{ Over weight } & \multicolumn{2}{|c|}{ Obesity } & \multicolumn{2}{|c|}{ Total } \\
\hline & $\mathbf{N}$ & $\%$ & $\mathbf{N}$ & $\%$ & $\mathbf{N}$ & $\%$ & $\mathbf{N}$ & $\%$ & $\mathbf{N}$ & $\%$ \\
\hline Not absences & 1 & $2.6 \%$ & 18 & $46.1 \%$ & 2 & $5.1 \%$ & 3 & $7.7 \%$ & 24 & $61.5 \%$ \\
\hline One time absences & 1 & $2.6 \%$ & 7 & $17.9 \%$ & 1 & $2.6 \%$ & 3 & $7.7 \%$ & 12 & $30.8 \%$ \\
\hline Two times absences & $\mathbf{0}$ & $0 \%$ & 2 & $5.1 \%$ & $\mathbf{0}$ & $0 \%$ & 1 & $2.6 \%$ & 3 & $7.7 \%$ \\
\hline
\end{tabular}

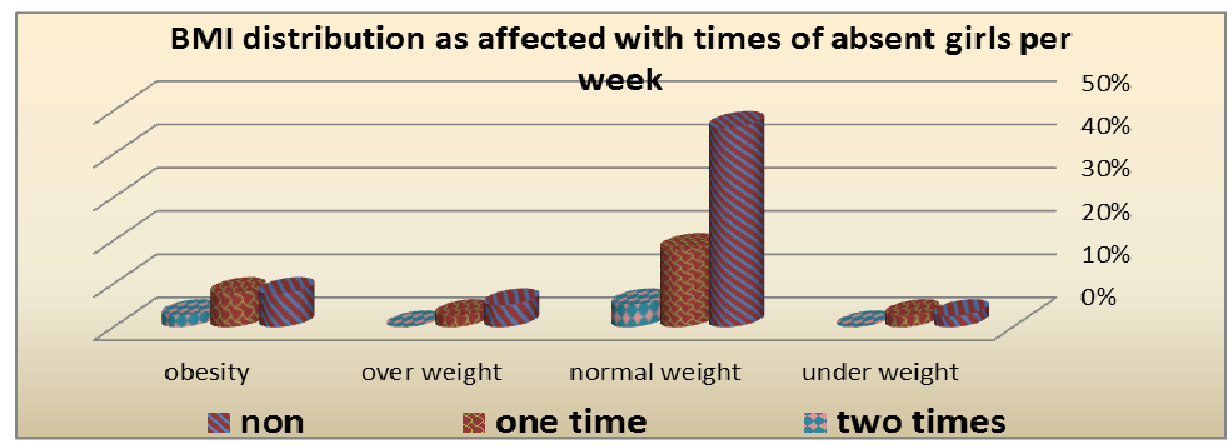

fig. (3) BMI distribution as affected with times of absent girls per week

$\mathrm{N}$ : number of girls

Table 6 and fig. 4 BMI distribution in girls as affected with Family number.

The result showed that, two cases were underweight in family contains four or five members, while obesity was obviously in families contains five members, then overweight was obviously in families contains 
four members, and normal weight were obviously in families contains four or five members.

This finding are in agreement with (EI metwaly, 1996) who showed that $2.1 \%$ of child were three members, then $28.6 \%$ of child were four members, then $56.8 \%$ were five and six members, and $12.4 \%$ were seven members.

Table (6): BMI distribution in girls as affected with Family member

\begin{tabular}{|c|c|c|c|c|c|c|c|c|}
\hline \multirow{2}{*}{ Family member } & \multicolumn{2}{|c|}{ Under weight } & \multicolumn{2}{|c|}{ Normal weight } & \multicolumn{2}{|c|}{ Over weight } & \multicolumn{2}{|c|}{ Obesity } \\
\hline & $\mathbf{N}$ & $\%$ & $\mathbf{N}$ & $\%$ & $\mathbf{N}$ & $\%$ & $\mathbf{N}$ & $\%$ \\
\hline Three members & $\mathbf{0}$ & $\mathbf{0 \%}$ & 3 & $7.7 \%$ & $\mathbf{0}$ & $0 \%$ & 1 & $2.6 \%$ \\
\hline Four members & 1 & $2.6 \%$ & 11 & $28 \%$ & 2 & $5.1 \%$ & 1 & $2.6 \%$ \\
\hline Five members & 1 & $2.6 \%$ & 8 & $20.5 \%$ & $\mathbf{0}$ & $\mathbf{0 \%}$ & 4 & $10.25 \%$ \\
\hline six members & $\mathbf{0}$ & $\mathbf{0 \%}$ & 4 & $10.25 \%$ & 1 & $2.6 \%$ & 1 & $2.6 \%$ \\
\hline seven members & $\mathbf{0}$ & $0 \%$ & 1 & $2.6 \%$ & $\mathbf{0}$ & $0 \%$ & $\mathbf{0}$ & $0 \%$ \\
\hline
\end{tabular}

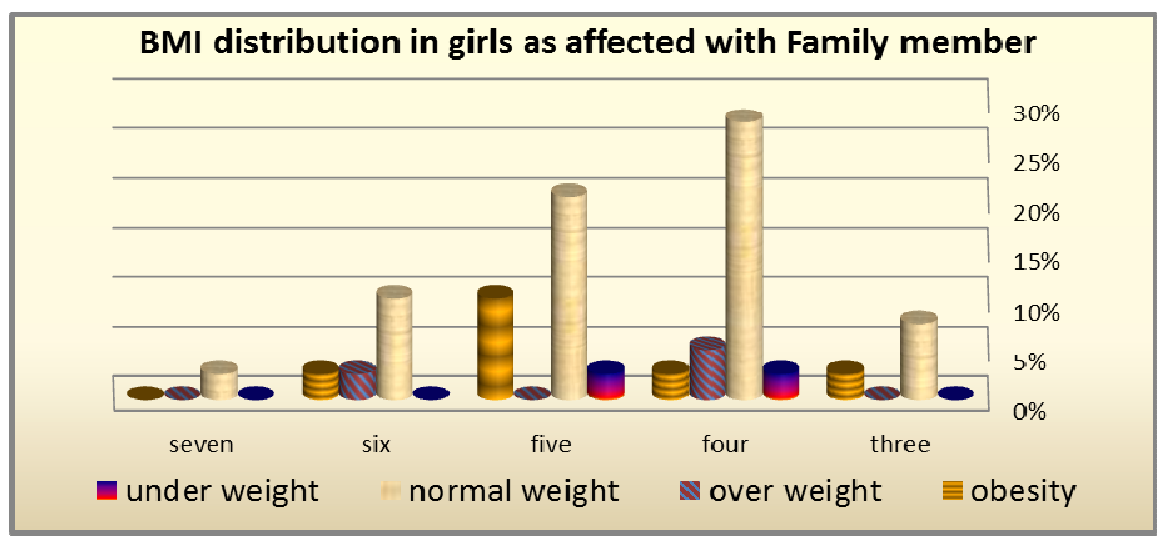

fig. (4) BMI distribution in girls as affected with Family member

$\mathrm{N}$ : number of girls

Table 7 and fig. 5 BMI distribution in girls as affected with member of their arrangement between brothers and sisters.

The result showed that, two cases were underweight the case of second and third arrangement, while obesity was obviously the case of in 
= Survey of Obesity Among Kindergarten Girls and Their mother's Awareness

first or the second, then overweight were clear in arranged the second child, while normal weight were obviously in the case of first child.

Table (7): BMI distribution in girls as affected with member of their arrangement

\begin{tabular}{||c|c|c|c|c|c|c|c|c||}
\hline \multirow{2}{*}{ BMI } & \multicolumn{2}{|c|}{ Under weight } & \multicolumn{2}{|c|}{ Normal weight } & \multicolumn{2}{|c|}{ Over weight } & \multicolumn{2}{|c|}{ Obesity } \\
\cline { 2 - 10 } Girls arrangement & $\mathrm{N}$ & $\%$ & $\mathrm{~N}$ & $\%$ & $\mathrm{~N}$ & $\%$ & $\mathrm{~N}$ & $\%$ \\
\hline \hline The first & $\mathbf{0}$ & $\mathbf{0 \%}$ & $\mathbf{1 3}$ & $\mathbf{3 3 . 3 \%}$ & $\mathbf{0}$ & $\mathbf{0 \%}$ & $\mathbf{4}$ & $\mathbf{1 0 . 2 5 \%}$ \\
\hline The second & 1 & $\mathbf{2 . 6 \%}$ & $\mathbf{7}$ & $\mathbf{1 7 . 9 \%}$ & $\mathbf{2}$ & $\mathbf{5 . 1 \%}$ & $\mathbf{3}$ & $\mathbf{7 . 7 \%}$ \\
\hline The third & $\mathbf{1}$ & $\mathbf{2 . 6 \%}$ & $\mathbf{4}$ & $\mathbf{1 0 . 2 5 \%}$ & $\mathbf{0}$ & $\mathbf{0 \%}$ & $\mathbf{0}$ & $\mathbf{0 \%}$ \\
\hline The fourth & $\mathbf{0}$ & $\mathbf{0 \%}$ & $\mathbf{3}$ & $\mathbf{7 . 7 \%}$ & $\mathbf{1}$ & $\mathbf{2 . 6 \%}$ & $\mathbf{0}$ & $\mathbf{0 \%}$ \\
\hline
\end{tabular}

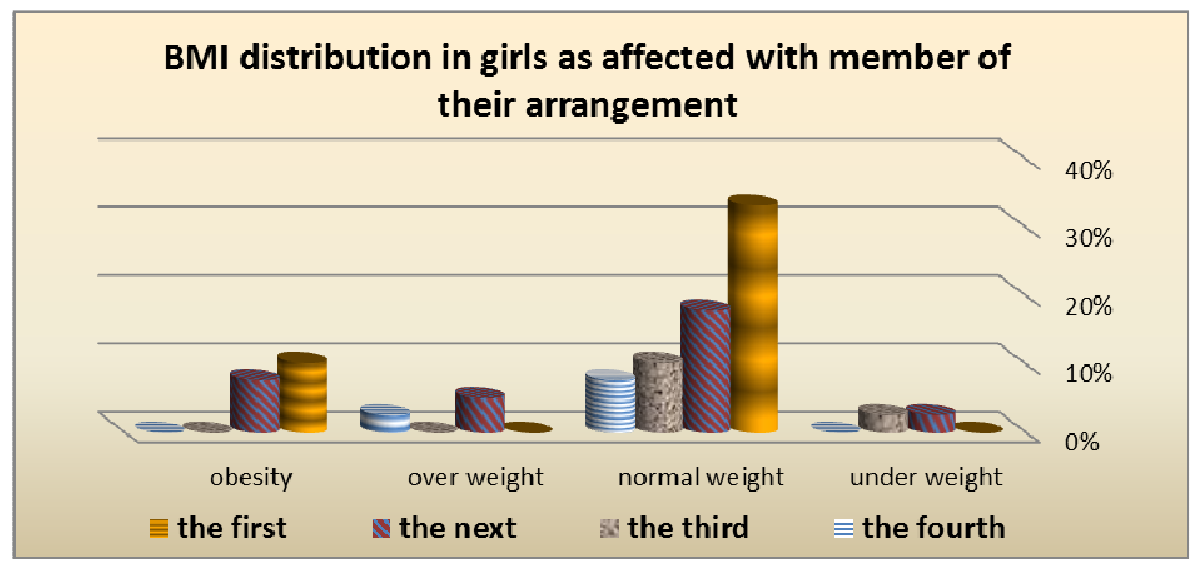

fig. (5) BMI distribution in girls as affected with member of their arrangement.

$\mathrm{N}$ : number of girls

Table 8 and fig. 6 BMI distribution in girls as affected with taken breakfast in school

The result showed that, one case were underweight who take breakfast before leaving to school, while obesity where in three cases whose don't take breakfast before leaving to school, on the other hand overweight, normal weight where similar in two cases. 


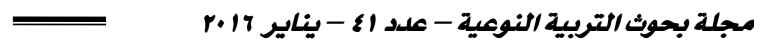

Table (8): BMI distribution in girls as affected with taken breakfast in school

\begin{tabular}{|c|c|c|c|c|c|c|c|c||}
\hline \multirow{2}{*}{$\begin{array}{l}\text { BMI } \\
\text { Take breakfast } \\
\text { before go to school }\end{array}$} & \multicolumn{2}{|c|}{ Under weight } & \multicolumn{2}{c|}{$\begin{array}{c}\text { Normal } \\
\text { weight }\end{array}$} & \multicolumn{2}{|c|}{$\begin{array}{c}\text { Over } \\
\text { weight }\end{array}$} & \multicolumn{2}{|c|}{ Obesity } \\
\cline { 2 - 10 } & $\mathrm{N}$ & $\%$ & $\mathrm{~N}$ & $\%$ & $\mathrm{~N}$ & $\%$ & $\mathrm{~N}$ & $\%$ \\
\hline \hline Yes & $\mathbf{1}$ & $\mathbf{3 . 6 \%}$ & $\mathbf{1 1}$ & $\mathbf{3 9 . 3 \%}$ & $\mathbf{1}$ & $\mathbf{3 . 6 \%}$ & $\mathbf{0}$ & $\mathbf{0 \%}$ \\
\hline No & $\mathbf{0}$ & $\mathbf{0 \%}$ & $\mathbf{1 1}$ & $\mathbf{3 9 . 3 \%}$ & $\mathbf{1}$ & $\mathbf{3 . 6 \%}$ & $\mathbf{3}$ & $\mathbf{1 0 . 7 \%}$ \\
\hline
\end{tabular}

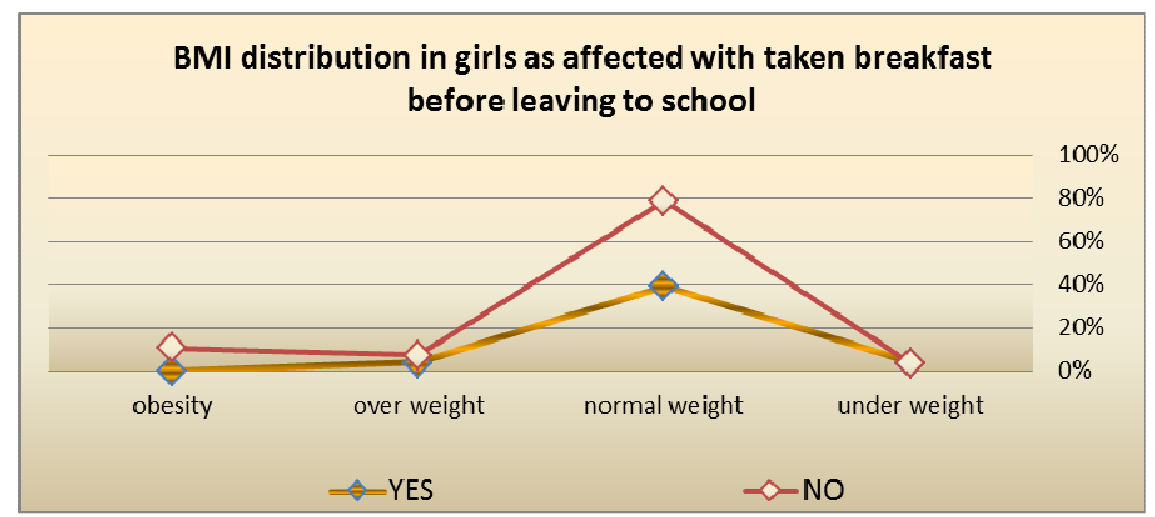

fig (6). BMI distribution in girls as affected with taken breakfast in school

$\mathrm{N}$ : number of girls

Table 9 showed the distribution of kind of home food intake during school day.

The most of the girls bring romy cheese sandwiches $92.9 \%$ to school then $39.3 \%$ bring fruits and juice, the few girls bring Yogurt, milk and Halvah $3.6 \%$. 
= Survey of Obesity Among Kindergarten Girls and Their mother's Awareness

Table (9): kind of home food intake during school day.

\begin{tabular}{||c||c|c||}
\hline Kind of home prepared food & $\mathrm{N}$ & $\%$ \\
\hline \hline Romy cheese sandwiches & 26 & $92.9 \%$ \\
\hline fruits & 11 & $39.3 \%$ \\
\hline juice & 11 & $39.3 \%$ \\
\hline egg sandwiches & 7 & $25 \%$ \\
\hline cucumber & 6 & $21.4 \%$ \\
\hline Luncheon & 3 & $10.7 \%$ \\
\hline cake & 3 & $10.7 \%$ \\
\hline Chocolate and candy & 3 & $10.7 \%$ \\
\hline Biscuit & 3 & $10.7 \%$ \\
\hline French fries & 2 & $7.1 \%$ \\
\hline jam & 2 & $7.1 \%$ \\
\hline Yogurt & 1 & $3.6 \%$ \\
\hline milk & 1 & $3.6 \%$ \\
\hline Halvah & 1 & $3.6 \%$ \\
\hline
\end{tabular}

$\mathrm{N}$ : number of girls

Table 10 and fig. 8 BMI distribution as affected with alternative food to home prepared food

The result showed that, one case were eating from school canteen was under weight, while most cases of obesity don't eat from school canteen, but all cases of overweight eat from school canteen, however normal weight the most girls were eating from school canteen.

Baxter et al. (2010) noted that for the total sample and subset, breakfast location was significantly associated with BMI; average BMI was larger for children with breakfast in the classroom than in the cafeteria. Significantly more kilocalories were observed eaten at breakfast in the classroom than in the cafeteria.

Also Sanjoy et al. (2012) showed that about two-third (65.6\%) of students take foods from the shops for their school meal and only one third (34.4\%) of the students bring foods from home for their school meals. 


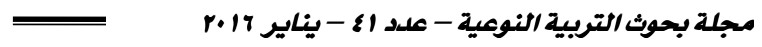

Table (10): BMI distribution as affected with alternative food to home prepared food

\begin{tabular}{|c|c|c|c|c|c|c|c|c|}
\hline \hline \multirow{2}{*}{$\begin{array}{l}\text { When girls } \\
\text { don't bring food from home }\end{array}$} & \multicolumn{2}{|c|}{$\begin{array}{c}\text { Under } \\
\text { weight }\end{array}$} & \multicolumn{2}{|c|}{$\begin{array}{c}\text { Normal } \\
\text { weight }\end{array}$} & \multicolumn{2}{|c|}{ Over weight } & \multicolumn{2}{|c|}{ Obesity } \\
\cline { 2 - 10 } & $\mathrm{N}$ & $\%$ & $\mathrm{~N}$ & $\%$ & $\mathrm{~N}$ & $\%$ & $\mathrm{~N}$ & $\%$ \\
\hline \hline Take food from school canteen & $\mathbf{1}$ & $\mathbf{3 . 6 \%}$ & $\mathbf{1 4}$ & $\mathbf{5 0 \%}$ & $\mathbf{2}$ & $\mathbf{7 . 1 \%}$ & $\mathbf{1}$ & $\mathbf{3 . 6 \%}$ \\
\hline Do not eat at school & $\mathbf{0}$ & $\mathbf{0 \%}$ & $\mathbf{8}$ & $\mathbf{2 8 . 6 \%}$ & $\mathbf{0}$ & $\mathbf{0 \%}$ & $\mathbf{2}$ & $\mathbf{7 . 1 \%}$ \\
\hline
\end{tabular}

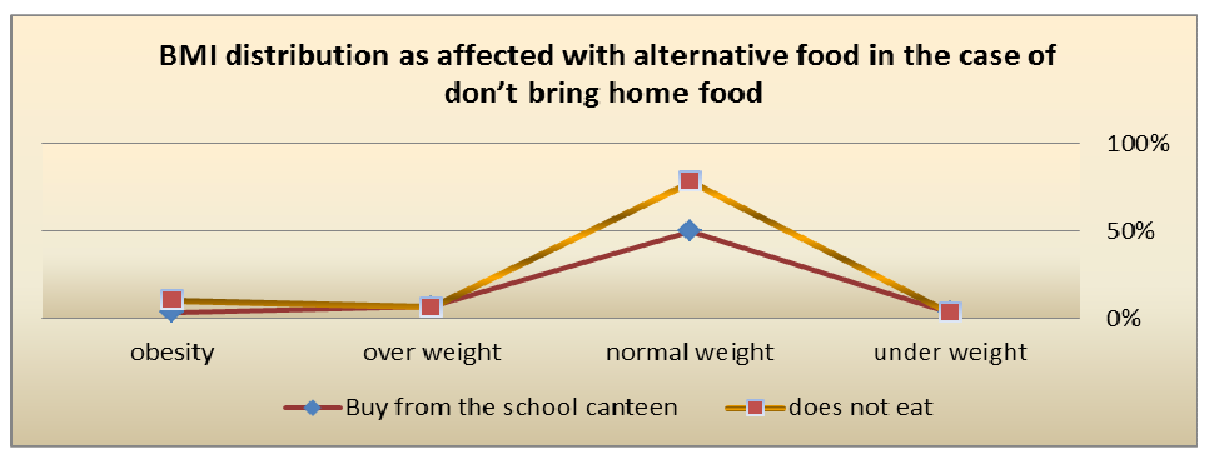

fig. (8) BMI distribution as affected with alternative food to home prepared food

$\mathrm{N}$ : number of girls

Table 11 and fig. 9 BMI distribution as affected with some kind of food intake from school canteen

Most food intake was Biscuit, Chocolate, Juice, Potato Ships they were 22(78.6\%), 15(53.6\%), $12(42.9 \%)$, and 11(39.3\%) respectively.

Lowest food intake was Sandwiches, soda, Fruit and candy, Bakery, Milk they were 3(10.7\%), 3(10.7\%), $2(7.1 \%), 2(7.1 \%)$, and 1(3.6\%) respectively 
= Survey of Obesity Among Kindergarten Girls and Their mother's Awareness

Table (11): BMI distribution as affected with some food intake from school canteen.

\begin{tabular}{|c|c|c|c|c|c|c|c|c|c|c|}
\hline \multirow{2}{*}{$\begin{array}{l}\text { BMI Some } \\
\text { food intake } \\
\text { from school canteen }\end{array}$} & \multicolumn{2}{|c|}{$\begin{array}{c}\text { Under } \\
\text { weight }\end{array}$} & \multicolumn{2}{|c|}{$\begin{array}{c}\text { Normal } \\
\text { weight }\end{array}$} & \multicolumn{2}{|c|}{$\begin{array}{c}\text { Over } \\
\text { weight }\end{array}$} & \multicolumn{2}{|c|}{ Obesity } & \multicolumn{2}{|c|}{ Total } \\
\hline & $\mathbf{N}$ & $\%$ & $\mathbf{N}$ & $\%$ & $\mathbf{N}$ & $\%$ & $\mathbf{N}$ & $\%$ & & \\
\hline Biscuit & 1 & $3.6 \%$ & 16 & $57.1 \%$ & 2 & $7.1 \%$ & 3 & $10.7 \%$ & 22 & $78.6 \%$ \\
\hline Chocolate & 1 & $3.6 \%$ & 12 & $42.9 \%$ & $\mathbf{0}$ & $0 \%$ & 2 & $7.1 \%$ & 15 & $53.6 \%$ \\
\hline Juice & 1 & $3.6 \%$ & 8 & $28.6 \%$ & 1 & $3.6 \%$ & 2 & $7.1 \%$ & 12 & $42.9 \%$ \\
\hline Potato Ships & $\mathbf{0}$ & $0 \%$ & 10 & $35.7 \%$ & $\mathbf{0}$ & $\mathbf{0 \%}$ & 1 & $3.6 \%$ & 11 & $39.3 \%$ \\
\hline Sandwiches & $\mathbf{0}$ & 0\% & 2 & $7.1 \%$ & $\mathbf{0}$ & $0 \%$ & 1 & $3.6 \%$ & 3 & $10.7 \%$ \\
\hline soda & $\mathbf{0}$ & $0 \%$ & 2 & $7.1 \%$ & $\mathbf{0}$ & $0 \%$ & 1 & $3.6 \%$ & 3 & $10.7 \%$ \\
\hline Fruit and candy & $\mathbf{0}$ & 0\% & 1 & $3.6 \%$ & $\mathbf{0}$ & $0 \%$ & 1 & $3.6 \%$ & 2 & $7.1 \%$ \\
\hline Bakery & $\mathbf{0}$ & 0\% & 1 & $3.6 \%$ & $\mathbf{0}$ & $\mathbf{0 \%}$ & 1 & $3.6 \%$ & 2 & $7.1 \%$ \\
\hline Milk & $\mathbf{0}$ & $0 \%$ & 0 & $0 \%$ & 0 & $0 \%$ & 1 & $3.6 \%$ & 1 & $3.6 \%$ \\
\hline
\end{tabular}

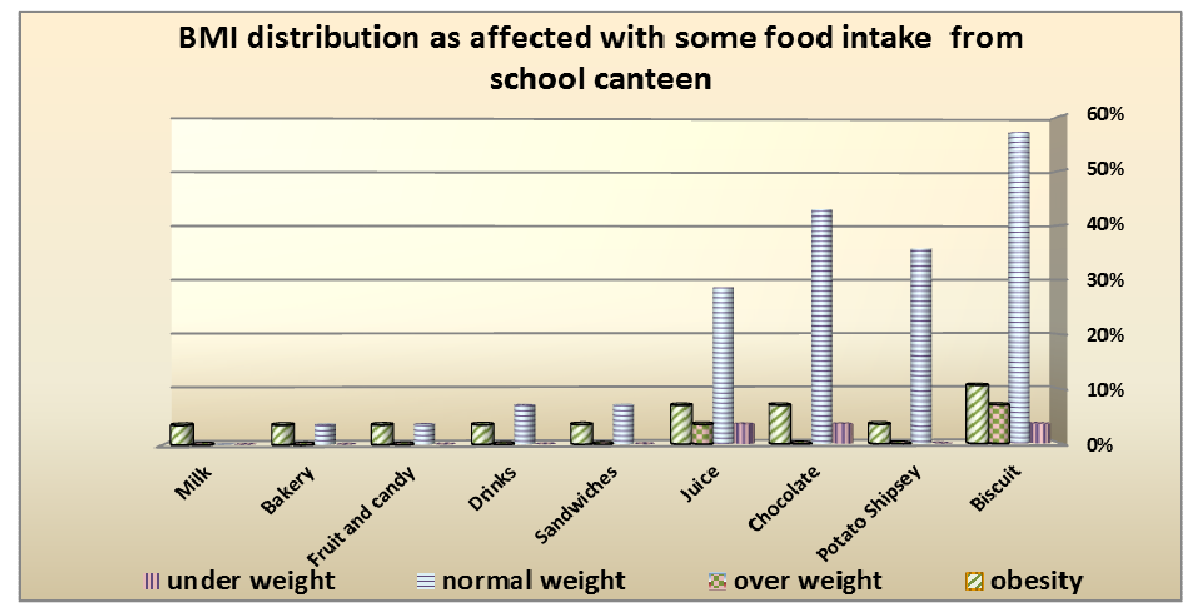

fig. (9) BMI distribution as affected with some food intake from school canteen.

$\mathrm{N}$ : number of girls

Table 12 Showed the distribution of the foods that preferred to girls. 
The most of girls requested chocolate, chicken, juice, candy, lowest food preferred included milk, salad, fish, apple, soda and cucumber. These result revealed decreasing food awareness.

Table (12): Distribution of the foods that preferred to girls.

\begin{tabular}{|c|c|c|c|}
\hline \multirow{8}{*}{$\begin{array}{l}\text { Most food } \\
\text { preferred }\end{array}$} & Kind of food & $\mathbf{N}$ & $\%$ \\
\hline & Chocolate & 7 & $25 \%$ \\
\hline & Chicken & 6 & $21.4 \%$ \\
\hline & Juice & 6 & $21.4 \%$ \\
\hline & Candy & 6 & $21.4 \%$ \\
\hline & Potato & 5 & $17.9 \%$ \\
\hline & Fruit & 5 & $17.9 \%$ \\
\hline & Pizza & 4 & $14.3 \%$ \\
\hline \multirow{10}{*}{$\begin{array}{l}\text { Mild food } \\
\text { preferred }\end{array}$} & Sandwiches & 3 & $10.7 \%$ \\
\hline & Biscuit & 3 & $10.7 \%$ \\
\hline & Vegetables & 3 & $10.7 \%$ \\
\hline & Pasta & 3 & $10.7 \%$ \\
\hline & Eggs & 2 & $7.1 \%$ \\
\hline & Yogurt & 2 & $7.1 \%$ \\
\hline & Burger & 2 & $7.1 \%$ \\
\hline & Kofta & 2 & $7.1 \%$ \\
\hline & meat & 2 & $7.1 \%$ \\
\hline & Shawarma & 2 & $7.1 \%$ \\
\hline \multirow{10}{*}{$\begin{array}{c}\text { Lowest food } \\
\text { preferred }\end{array}$} & Milk & 1 & $3.6 \%$ \\
\hline & Salad & 1 & $3.6 \%$ \\
\hline & Fish & 1 & $3.6 \%$ \\
\hline & Tahini & 1 & $3.6 \%$ \\
\hline & Potato Chips & 1 & $3.6 \%$ \\
\hline & Rice & 1 & $3.6 \%$ \\
\hline & Cakes & 1 & $3.6 \%$ \\
\hline & soda & 1 & $3.6 \%$ \\
\hline & Cucumber & 1 & $3.6 \%$ \\
\hline & apple & 1 & $3.6 \%$ \\
\hline
\end{tabular}

$\mathrm{N}$ : number of girls 
= Survey of Obesity Among Kindergarten Girls and Their mother's Awareness

\section{REFERENCES}

- Al Nuaim AR, Bamgboye EA, Al Herbish A (1996): The pattern of growth and obesity in Saudi Arabian male school children, Int J Obes Relat Metab Disord ; 20:1000-5.

- Almeida CA, Del Ciampo LA, Ricco RG, Silva Jr SM, Naves RB, Pina JF(2003): Assessment of mid-upper arm circumference as a method for obesity screening in preschool children. J Pediatr (Rio J);79:455e60.

- Baxter. S, Hardin. J, Guinn. C, Royer. J, Mackelprang. A and Devlin. C (2010): Children's body mass index, participation in school meals, and observed energy intake at school meals, International Journal of Behavioral Nutrition and Physical Activity, 7:24 doi:10.1186/1479-5868-7-24.

- Cummins S, McKay L, Macintyre S (2005): McDonald's restaurants and neighborhood deprivation in Scotland and England. Am J Prev Med ; 29:308-10.

- El metwaly M (1996): Prevalence of obesity between school children, Faculty of Home economics M.Sc.

- Fraser LK, Edwards KL, Cade J(2010): The geography of Fast Food outlets: a review. Int J Environ Res Public Health ; 7:2290-308.

- Hassan H A (2003): Egyptian National Survey of Obesity

- James PT (2004): Obesity: The worldwide epidemic. Clinics in Dermatology, 22:276-280.

- Kelishadi R, Pour MH, Sarraf-Zadegan N, Sadry GH, Ansari R, Alikhassy H, Bashardoust N(2003): Obesity and associated modifiable environmental factors in Iranian adolescents: Isfahan Healthy Heart Program - Heart Health Promotion from Childhood. Pediatr Int, 45:435-442.

- Keynote (2006): UK Fast Food and Home Delivery Outlets.http://www.reportlinker.com/p040211/UK-Fast-Food-and-HomeDelivery-Outlets.html .

- Kosti RI1, Panagiotakos DB. (2006): The epidemic of obesity in children and adolescents in the world, Cent Eur J Public Health., 14(4) :151-9.

- Livingstone MB (2001): Childhood obesity in Europe: a growing concern. Public Health Nutr, 4:109-116 
- Lowes, j and Tiggemann, M (2010): Body dissatisfaction, dieting awareness and the impact of parental influence in young children, Volume 8, Issue 2, pages 135-147.

- MacIntyre S, McKay L, Cummins S (2005): Out-of-home food outlets and area deprivation: case study in Glasgow; UK. J Behav Nutr Phys Act 5;2:16-22.

- Mark S. Tremblay and J. Douglas Willms (2000): Secular trends in the body mass index of Canadian children, Canadian Medical Association Journal, vol. 163 no. 11 1429-1433

- Mazıcio_glu MM, Hatipo_glu N, Oztürk A, Cicsek B, Ustünbas, HB, Kurto_glu S(2010): Waist circumference and mid-upper arm circumference in evaluation of obesity in children aged between 6 and 17 years. J Clin Res Pediatr Endocrinol;2:144e50.

- NHS Information Centre for Health and Social Care(2011): Statistics On Obesity, Physical Activity and Diet: England. http://www.ic.nhs.uk

- Nicklas TA, T. B, K.W. C, G. B (2001): Eating Patterns, Dietary Quality and Obesity. Journal of the American College of Nutrition, 20:599-608.

- Ogden C, Carroll M (2010): Prevalence of obesity among children and adolescents: United States, trends 1963-1965 through 2007-2008. Retrieved from National center for health statistics, Center for Disease Control and Prevention.

- Qiang Lu, Rui Wang, Dong-Hui Lou, Chun-Ming Ma, Xiao-Li Liu, Fu-Zai Yin ( 2014): Mid-upper-arm Circumference and Arm-to-height Ratio in Evaluation of Overweight and Obesity in Han Children, journal of PEDIATRICS AND NEONATOLOGY Volume 55, Issue 1, Pages 14-19

- Sanjoy Saha, Md Khurshidul Zahid, Sabrina Rasheed (2012): The Study of the Level of Knowledge, Attitude, Practices (KAP) as well as the Effects of School Environment on the Nutritional Status of Children (7-12) Coming from Affluent Families in the Dhaka City in Bangladesh, Bangladesh Journal of Nutrition, Vol 24-25.

- Schanzenbach D W (2009): Do School Lunches Contribute to Childhood Obesity? , Journal of Human Resources, vol. 44 no. 3 684-709

- Schlosser E (2002): Fast Food Nation. London, UK: Penguin. 
- Simmons D, McKenzie A, Eaton S (2005): Choice and availability of takeaway and restaurant food is not related to the prevalence of adult obesity in rural communities in Australia. Int J Obes (Lond) ;29:703-10.

- Stanton B, Cole M, Galbraith J, Li X, Pendleton S, Cottrel L (2004): Randomized trial of a parent intervention: parents can make a difference in longterm adolescent risk behaviors, perceptions, and knowledge. Arch Pediatr Adolesc Med ;158:947-55.

- The National Center for Health Statistics in collaboration and the National Center for Chronic Disease Prevention and Health Promotion (2000). http://www.cdc.gov/growthcharts

- Whitaker RC, Wright JA, Pepe MS, Seidel KD, Dietz WH (1997): Predicting obesity in young adulthood from childhood and parental obesity. New England Journal of Medicine, 337:869-873.

- World Health Organisation WHO (2015): Obesity and overweight, WHO Media centre, http://www.who.int/mediacentre/factsheets/fs311/en/

- World Health Organization WHO (2014): Global Nutrition Targets 2025: Childhood overweight policy brief, WHO/NMH/NHD/14.6. 


\section{دراسة هسحية عن انتشار السمنة بين الفتيات}

\section{برياض الأطفال والوعي الغذائي للألههات}

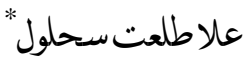

$$
\text { الملخص العربي }
$$

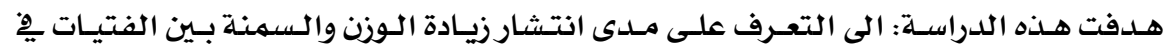

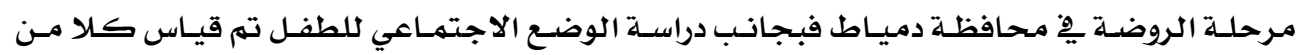
الطـول والـوزن كلتعـرف على كتلـة الجسسم، كهـا تم قيـاس محسيط الـذراع، وعمـل اسـتبـيانات لمعرفـة

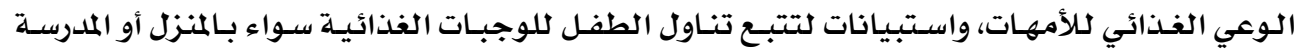

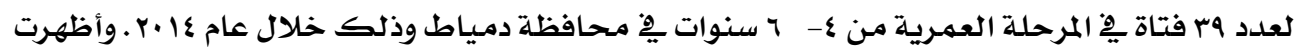

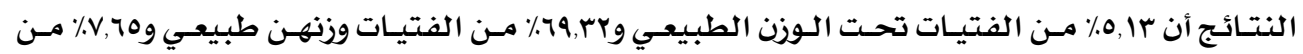
الفتيات وزنهن أعلى من الطبيعي و 1V,09٪ مـن الفتيات يعانين من السهـنة، كمـا أثبتـت الدراسـة عدم ارتباط كتلـة الجسم لـلأطفال بـالوعي الغذائي لدى الأمهات على عكس المتوقع، وبمـا يستدعي اعـادة

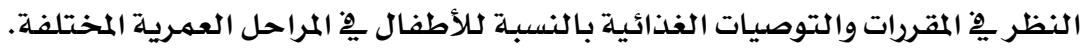

